\title{
Correction to: Divergent controls on carbon concentration and persistence between forests and grasslands of the conterminous US
}

\author{
K. A. Heckman (D) - L. E. Nave - M. Bowman - A. Gallo - J. A. Hatten • \\ L. M. Matosziuk - A. R. Possinger - M. SanClements • B. D. Strahm • \\ T. L. Weiglein · C. Rasmussen - C. W. Swanston
}

Published online: 30 March 2021

(C) The Author(s) 2021

Correction to: Biogeochemistry

https://doi.org/10.1007/s10533-020-00725-z

The article "Divergent controls on carbon concentration and persistence between forests and grasslands of the conterminous US", written by K. A. Heckman, L. E. Nave, M. Bowman, A. Gallo, J. A. Hatten, L.

The original article can be found online at https:// doi.org/10.1007/s10533-020-00725-z.

K. A. Heckman $(\bowtie) \cdot$ C. W. Swanston

Northern Research Station, USDA Forest Service,

Houghton, MI 49931, USA

e-mail: katherine.a.heckman@usda.gov

L. E. Nave

Biological Station, University of Michigan, Pellston,

MI 49769, USA

L. E. Nave

Dept. of Ecology and Evolutionary Biology, University of Michigan, Ann Arbor, MI 48109, USA

\section{Bowman}

Environmental Studies Program, University of Colorado,

Boulder, Boulder, CO 80303, USA

M. Bowman · M. SanClements

INSTAAR University of Colorado, Boulder, Boulder,

CO 80303, USA
M. Matosziuk, A. R. Possinger, M. SanClements, B. D. Strahm, T. L. Weiglein, C. Rasmussen, and C. W. Swanston, was originally published electronically on the publisher's internet portal on 232 November 2020 without open access. With the author(s)' decision to opt for Open Choice the copyright of the article changed on 8 March 2021 to (c) The Authors 2021 and the article is forthwith distributed under a Creative Commons Attribution 4.0. International License, which permits use, sharing, adaptation, distribution

\section{A. Gallo · J. A. Hatten · L. M. Matosziuk \\ Forest Engineering, Resources and Management, Oregon State University, Corvallis, OR 97330, USA}
A. R. Possinger - B. D. Strahm - T. L. Weiglein
Department of Forest Resources and Environmental
Conservation, Virginia Tech, Blacksburg,
VA 24061, USA
M. SanClements
National Ecological Observatory Network, Boulder,
CO 80301, USA
C. Rasmussen
Department of Environmental Science, University of Arizona, Tucson, AZ 85721, USA 
and reproduction in any medium or format, as long as you give appropriate credit to the original author(s) and the source, provide a link to the Creative Commons licence, and indicate if changes were made. The images or other third party material in this article are included in the article's Creative Commons licence, unless indicated otherwise in a credit line to the material. If material is not included in the article's Creative Commons licence and your intended use is not permitted by statutory regulation or exceeds the permitted use, you will need to obtain permission directly from the copyright holder. To view a copy of this licence, visit http://creativecommons.org/ licenses/by/4.0.
Open Access This article is licensed under a Creative Commons Attribution 4.0 International License, which permits use, sharing, adaptation, distribution and reproduction in any medium or format, as long as you give appropriate credit to the original author(s) and the source, provide a link to the Creative Commons licence, and indicate if changes were made. The images or other third party material in this article are included in the article's Creative Commons licence, unless indicated otherwise in a credit line to the material. If material is not included in the article's Creative Commons licence and your intended use is not permitted by statutory regulation or exceeds the permitted use, you will need to obtain permission directly from the copyright holder. To view a copy of this licence, visit http://creativecommons.org/licenses/by/4.0/.

Publisher's Note Springer Nature remains neutral with regard to jurisdictional claims in published maps and institutional affiliations. 